\title{
Gene Action For Yield Contributing Character In Bottle Gourd
}

\author{
AKM Quamruzzaman, M.M.R. Salim, L. Akhter, M.M. Rahman, M.A.Z. Chowdhury
}

\begin{abstract}
A study of the attributes for yield components of $21 \mathrm{F1}$ 's and their seven parents in $7 \times 7$ diallel (excluding reciprocals) of bottle gourd [Lagenaria siceraria (Mol.) Standl.] was conducted at the Olericulture Division of Horticulture Research Centre, Bangladesh Agricultural Research Institute (BARI), Gazipur, Bangladesh during 201819. The graphical and the component of variance analysis revealed that non-additive gene action were dominant in all the characters studied. But the average degree of dominance was over dominance in the inheritance of maximum traits in except fruit length, fruit diameter, endocarp thickness showed the partial dominance for the genes controlling these characters. The values of the ratio of number of total dominant and recessive gene estimated were one or more than one for most of the characters except fruit length and fruits number per plant indicating the asymmetrical distribution of dominant and recessive alleles in the parents for the eight characters and an excess of dominant gene is indicated. Broad sense heritability was higher heritability for all the parameters but in narrow sense heritability were higher heritability for fruit length, fruit diameter, endocarp thickness indicating their high heritable control nature. The $\mathrm{Wr} / \mathrm{Vr}$ graphs showed dominance effect of gene was observed in maximum characters. The graphical analysis indicated wide genetic diversity among the parents.
\end{abstract}

Index Terms- Bottle gourd [Lagenaria siceraria (Mol.) Standl.J, gene action, heterosis, combining ability, additive and non-additive gene actions.

\section{INTRODUCTION}

Bottle gourd [Lagenaria siceraria (mol.) standl.] is an important winter vegetable crop but it is cultivating year round now a days. Since there exists a considerable variability of this crop in Bangladesh, possibilities to develop high yielding varieties through breeding approaches like selection or hybridization. A soundbreeding programme provides the opportunity to produce

Published on June 05, 2020.

AKM Quamruzzaman, Olericulture Division, Horticulture Research Centre, Bangladesh Agricultural Research Institute, Gazipur, Bangladesh. (email: akmqzs@gmail.com)

M.M.R. Salim, Olericulture Division, Horticulture Research Centre, Bangladesh Agricultural Research Institute, Gazipur, Bangladesh. (email: msalim.hrc@gmail.com)

L. Akhter, Olericulture Division, Horticulture Research Centre, Bangladesh Agricultural Research Institute, Gazipur, Bangladesh. (email: limuakter@gmail.com)

M.M. Rahman, Bangladesh Agricultural Research Council, Dhaka, Bangladesh. (email: m.rahman6820@yahoo.com)

M.A.Z. Chowdhury, Bangladesh Agricultural Research Council, Dhaka, Bangladesh.

(email: zilani71@gmail.com) high yielding varieties of a crop with superior quality. However, the development of a meaningful breeding programme needs information on the nature of gene actions controlling the economic characters and other characters of importance. Knowledge of genetic architecture of the characters under improvement is essential for adopting appropriate breeding procedure. Such knowledge leads the plant breeder to develop new commercial varieties of the crop. Gardner (1963) stressed that information on variation attributable to genetic differences and also on the relationship among various quantitative traits is fundamentally significant in crop improvement programme.

The existence of significant amount of non-additive gene action is a prerequisite for exploitation of heterosis. The specific combining ability variance largely is the measure of dominance variance. If heterosis is high for specific cross and observations made are true for economic trait like yield, it is possible to utilize the cross as a commercial hybrid provided that the pollination system of the crop permits commercial seed production of hybrids or there exists a male sterility, fertility restoration system [6]. [25] revealed that the gene distribution among the parents was found asymmetry as the proportion of dominant and recessive genes exceeds one for all the studied characters except vine length. Instead, there is a great scope for the improvement of this crop through hybridization. The nature and magnitude of gene action is an important factor in developing an effective breeding programme. The diallel analysis provides information of the genetically control of a set of parents in the early generations [13]. It indicates ample scope of exploitation of hybrid vigour in bottle gourd. Considering aforesaid facts, the prime objective of present study is to study the gene action through diallel mating design for ten yield contributing traits in bottle gourd.

\section{MATERIALS AND METHODOLOGY}

\section{A. Experimental site}

The experiment was conducted at the Olericulture Division of Horticulture Research Centre, Bangladesh Agricultural Research Institute (BARI) during 2018-19. The experimental field was at $23.9920^{\circ} \mathrm{N}$ Latitude and $90.4125^{\circ}$ E Longitudes having an elevation of $8.2 \mathrm{~m}$ from sea level under agro-ecological zone (AEZ) 28 [1]. The experimental site is situated in the sub-tropical climatic zone and characterized by scanty rainfall during the experimental time. The average minimum and maximum temperature were $18.37^{\circ} \mathrm{C}$ and $29.37^{\circ} \mathrm{C}$ and the average relative humidity varied from 55.55 to $75.70 \%$. The soil of the experimental 
field was sandy clay loam in texture having a $\mathrm{pH}$ range around 6.0.

\section{B. Plant materials}

Twenty one cross combinations viz., P1xP2, P1xP3, P1xP4, $\mathrm{P} 1 \times \mathrm{P} 5, \mathrm{P} 1 \times \mathrm{P} 6, \mathrm{P} 1 \times \mathrm{P} 7, \mathrm{P} 2 \mathrm{xP} 3, \mathrm{P} 2 \mathrm{xP} 4, \mathrm{P} 2 \mathrm{xP} 5, \mathrm{P} 2 \mathrm{xP} 6$, $\mathrm{P} 2 \times \mathrm{P} 7, \mathrm{P} 3 \times \mathrm{P} 4, \mathrm{P} 3 \times \mathrm{P} 5, \mathrm{P} 3 \times \mathrm{P} 6, \mathrm{P} 3 \times \mathrm{P} 7, \mathrm{P} 4 \times \mathrm{P} 5, \mathrm{P} 4 \times \mathrm{P} 6$, $\mathrm{P} 4 \times \mathrm{P} 7, \mathrm{P} 5 \times \mathrm{P} 6, \mathrm{P} 5 \times \mathrm{P} 7$ and $\mathrm{P} 6 \times \mathrm{P} 7$ along with seven parents viz., P1[code LS14], P2[code LS01], P3 [code LS02], P4[code LS03], P5 [code LS04], [P6 code LS07], P7 [code LS09] of bottle gourd were used in this study. The seeds of these germplasm were sown on the seedbed on 05October, 2018. Twenty days old seedlings were transplanted in the main field on 25October, 2018.

\section{Experimental design and layout}

The experiment was laid out in a Randomized Complete Block design with three replications. The unit plot size was $10.0 \times 2.0 \mathrm{~m}$ maintaining $2.0 \times 2.5 \mathrm{~m}$ spacing and $0.5 \mathrm{~m}$ drain.

\section{Land, pit preparation and fertilization}

The land was fertilized with organic fertilizer, N, P, K, S, B and Zn@10000, 80, 45, 88, 25, 1.8 and 4.5 kg/ha, respectively. Half of organic fertilizer and all of $\mathrm{S}, \mathrm{Zn}$ and B each of P and K@30 kg/ha were applied during final land preparation. Rest of organic fertilizer and P and K @ $15 \mathrm{~kg} /$ ha were applied as basal in pit. Rest of $\mathrm{N}$ and $\mathrm{K}$ were applied after 20 days of transplanting in 4 equal installments at 20 days interval starting.

\section{E. Intercultural operation and plant protection}

The soil around the base of each seedling was pulverized after the establishment of seedlings. Necessary intercultural operations were done to ensure normal growth and development of the plants. Bamboo sticks were used to support the growing plants and allowed them to grow along string netting. Irrigation was applied to the plants in pits as and when required. Adult red pumpkin beetle was controlled by hand removal twice daily whereas fruit fly was controlled at the fruiting stage using poison bait.

\section{F. Data recorded}

Data were recorded on the following parameters viz., days to 1st harvest, fruit length, fruit diameter, exocarp thickness, TSS, branches per plant, vine length, fruits number per plant, average fruit weight and yield per plant. Genetic components of variation were calculated for the analysis of numerical approach followed the method given by $[2,8$, $12]$.

\section{G. Statistical analysis}

Diallel analysis for the components of genetic variances and $\mathrm{Wr}-\mathrm{Vr}$ graphs for all the characters studied were done according to $[8,9]$. A diallel table was prepared from the averages over all the three replicates and the following statistics were estimated.

Numerical diallel analysis: Graphical analysis was performed followed by the determination of genetic variance components (Additive and dominance variances) together with allied parameters.
Computation of variance components and allied parameters in $F_{1}$ diallel: Using the values of different statistics computed earlier the variance components and allied parameters were calculated according to [21] as follows.

$$
\begin{aligned}
& \mathrm{D}=\mathrm{V}_{\mathrm{OLO}}-\mathrm{E} \\
& \mathrm{F}=2 \mathrm{~V}_{\mathrm{OLO}}-4 \mathrm{~W}_{\mathrm{OLO}}-2(\mathrm{n}-2) .(\mathrm{E} / \mathrm{n}) \\
& \mathrm{H}_{1}=\mathrm{V}_{\mathrm{OLO}}-4 \mathrm{VL}-4 \mathrm{~W}_{\mathrm{OLO}}-(3 \mathrm{n}-2) \mathrm{E} / \mathrm{n} \\
& \mathrm{H}_{2}=4 \mathrm{~V}_{\mathrm{ILI}}-4 \mathrm{~V}_{\mathrm{OL}}-2 \mathrm{E} \\
& \mathrm{h}^{2}=4\left(\mathrm{ML}-\mathrm{M}_{\mathrm{LO}}\right)^{2}-4(\mathrm{n}-1) .\left(\mathrm{E} / \mathrm{n}^{2}\right) \\
& \mathrm{E}=1 / \mathrm{r}[\mathrm{RSS}+\mathrm{ESS}] /[(\mathrm{r}-1)+(\mathrm{c}-1)(\mathrm{r}-1)] \\
& \text { Mean degree of dominance }=\sqrt{ }\left(\mathrm{H}_{1} / \mathrm{D}\right)
\end{aligned}
$$

Proportion of dominant genes with positive or negative sign $=\left(\mathrm{H}_{2} / 4 \mathrm{H}_{1}\right)$

Proportion of dominant and recessive genes $=\sqrt{[}\left[\left(4 \mathrm{DH}_{1}\right)+\right.$ $\mathrm{F}] / \sqrt{ }\left[\left(4 \mathrm{DH}_{1}\right)-\mathrm{F}\right]$

Number of gene blocks exhibiting dominance $=h^{2} / \mathrm{H}_{2}$ $\mathrm{h}^{2} \mathrm{~ns}=[\mathrm{D} / 4] /\left[\mathrm{D} / 4+\mathrm{H}_{1} / 4+\mathrm{E}-\mathrm{F} / 4\right]$

Where,

$\mathrm{D}=$ additive variance

$\mathrm{F}=$ mean Covariance of additive and dominance

$\mathrm{H}_{1}=$ dominance variance

$\mathrm{H}_{2}=$ proportion of positive or negative genes

$\mathrm{h}^{2}=$ dominance effect

$\mathrm{E}=$ environmental variance

$\mathrm{n}=$ Number of parents

$\mathrm{r}=$ number of replications

$\mathrm{V}_{\mathrm{oLo}}=$ Variance of parents

$\mathrm{V}_{\mathrm{oL} 1}=$ Variance of array means

$\mathrm{W}_{\mathrm{oLo} 1}=$ Average $\mathrm{Wr}$

$\mathrm{V}_{1 \mathrm{~L} 1}=$ Average $\mathrm{Vr}$

$\left(\mathrm{M}_{\mathrm{L} 1}-\mathrm{ML}_{\mathrm{L}}\right)^{2}=1 / \mathrm{n}[(\mathrm{Grand}$ total/n)-parental total $]$

$\mathrm{h}^{2} \mathrm{~ns}=$ heritability in narrow sense

\section{DISCUSSION}

\section{A. Genetic components}

Estimates of components of genetic variations and the various ratios computed from them are presented in the Table 1. The trend of estimates and ratios has similarity except few cases. The component $\mathrm{D}$ which reflects additive genetic variance were highly significant for most of the characters studied except the character vine length, fruits number per plant (Table 1). So, this indicated the importance of additive gene effects in the inheritance of all the ten characters studied viz., days to 1st harvest, fruit length, fruit diameter, exocarp thickness, TSS, branches per plant, vine length, fruits number per plant, average fruit weight and yield per plant. The sign of component $F$ indicates the relative frequencies of dominant and recessive alleles in the parents was positive and greater than zero which expressed that dominant alleles were more frequent than recessive alleles in the other characters except fruit length, exocarp thickness, fruits number per plant. The component $\mathrm{H}_{1}$, which measures the dominance variation, was highly significant for all the parameters studied indicating the importance of dominance gene effects in controlling them. The component $\mathrm{H}_{2}$ was also highly significant for all the traits indicating dominance with asymmetry of positive and negative effects. 
Thus, the highly significant values of the components $\mathrm{D}, \mathrm{H}_{1}$ and $\mathrm{H}_{2}$ indicated the importance of both additive and dominant gene effects in the expression of all the characters studied. The magnitude of $\mathrm{D}$ was higher than $\mathrm{H}_{1}$ in case of fruit length, fruit diameter, and endocarp thickness. But the other characters, the magnitude of $\mathrm{H}_{1}$ was higher than the magnitude of $\mathrm{D}$ indicating the predominance of dominance effect over additive effects in the expression of the traits, which is in consonance with the findings of [10, 20, 24, 26]. The component h2, which measures the dominant effect over all the loci, was also highly significant for most of the characters except exocarp thickness indicating higher degree of dominance effects i.e. sum total over all the loci in heterozygous phase in all the crosses. The results are in agreement with findings of [17, 23] whereas [25] reported that predominance of non-additive gene action for all studied traits except fruit length emphasize that the heterosis breeding has prime importance to acquire highyielding bottle gourd hybrid. The environmental component exhibited highly significant values except in branches per plant, vine length indicating influence of environmental factors for the expression of the traits studied. However, the magnitude of $E$ for each character was much lower than the respective value of $\mathrm{D}$ and $\mathrm{H}_{1}$ except fruits number per plant. This indicated that the environmental influence over the character expression was less than the additive and dominant effects. The findings are in agreement with [22, $24,26]$. The average degree of dominance $\left(\mathrm{H}_{1} / \mathrm{D}\right)^{0.5}$ was greater than one for most of the characters indicating over dominance in the inheritance of those traits. But fruit length, fruit diameter, endocarp thickness showed the value as less than one indicating the partial dominance for the genes controlling these characters. [14] also reported similar findings of over dominance and partial dominance while [7] reported only over dominance for all characters. The ratio of $\mathrm{H}_{2} / 4 \mathrm{H}_{1}$ provides an estimate of the average frequency of positive and negative alleles in all the parents. The values of this ratio for all the ten characters studied were less than
0.25 indicating unequal distribution of positive and negative alleles. However, the value of the ratio in case of fruit diameter, exocarp thickness, fruits number per plant were very closer to 0.25 indicated almost equal distributions of positive and negative alleles in the parents for these traits.

The ratio of $\left\{\left(4 \mathrm{DH}_{1}\right) 0.5+\mathrm{F}\right\} /\left\{\left(4 \mathrm{DH}_{1}\right) 0.5-\mathrm{F}\right\}$ estimates the relative proportion of dominant and recessive alleles in the parents. The values of the ratio of number of total dominant and recessive gene estimated were one or more than one for most of the characters except fruits number per plant indicating the asymmetrical distribution of dominant and recessive alleles in the parents. [14] also reported such findings while [7] reported symmetrical distribution of dominant and recessive alleles in the parents. The higher proportions of dominant genes observed in most of the traits are in agreement with the findings of [15] and [4]. The ratio of $\mathrm{h} 2 / \mathrm{H}_{2}$ estimates the number of gene or group of genes which control the character exhibiting the degree of dominance. The $\mathrm{h} 2 / \mathrm{H}_{2}$ values for the character fruit length, yield per plant were $2.09,2.40$, respectively, indicated the involvement of 1 to 2 genes or gene groups in the inheritance of these characters as per their own ratio. The other characters having this ratio smaller than one indicated the involvement of single dominant gene or one group of genes which are responsible for their genetically control. Broad sense heritability was higher in all the parameters studied but heritability in narrow sense was higher or relatively higher for fruit length, fruit diameter, indicating these characters were highly heritable to moderately heritable. Days to edible fruit maturity had the lowest heritability with the other traits as low to intermediate (Table 1). [14] reported higher heritability for pod length, pod diameter, pod per plant, pod weight, pod yield and moderate heritability for days to pod maturity which is identical with the findings of the present investigation. They have reported lower heritability for earliness. This finding also suggests moderately high heritability for the traits.

TABLE 1. ESTIMATES OF GENETIC COMPONENTS OF VARIATION AND RATIOS FOR DIFFERENT CHARACTERS IN BOTTLE GOURD

\begin{tabular}{|c|c|c|c|c|c|c|c|c|c|c|}
\hline \multirow{2}{*}{$\begin{array}{l}\text { Coefficient of } \\
\text { variation/ ratio }\end{array}$} & \multicolumn{9}{|c|}{ Character } & \multirow[b]{2}{*}{$\begin{array}{c}\text { Yield per } \\
\text { plant }\end{array}$} \\
\hline & $\begin{array}{c}\text { Days to } \\
\text { 1st } \\
\text { harvest }\end{array}$ & $\begin{array}{l}\text { Fruit } \\
\text { length }\end{array}$ & $\begin{array}{c}\text { Fruit } \\
\text { diameter }\end{array}$ & $\begin{array}{l}\text { Exocarp } \\
\text { thickness }\end{array}$ & TSS & $\begin{array}{l}\text { Branches } \\
\text { per plant }\end{array}$ & $\begin{array}{l}\text { Vine } \\
\text { length }\end{array}$ & $\begin{array}{c}\text { Fruits } \\
\text { number } \\
\text { per plant }\end{array}$ & $\begin{array}{c}\text { Average } \\
\text { fruit } \\
\text { weight }\end{array}$ & \\
\hline \multirow[t]{2}{*}{$\mathrm{D}$} & $4.04 * *$ & $89.93 * *$ & $6.90 * *$ & $0.04 * *$ & $0.17 * *$ & $22.23 * *$ & 0.43 & 0.01 & $0.04 * *$ & $8.56^{* *}$ \\
\hline & \pm 0.83 & \pm 4.30 & \pm 0.41 & \pm 0.01 & \pm 0.01 & \pm 3.93 & \pm 0.33 & \pm 0.62 & \pm 0.01 & \pm 3.20 \\
\hline \multirow[t]{2}{*}{$\mathrm{F}$} & 2.90 & -13.66 & 1.69 & -0.01 & $0.17 * *$ & $41.51 * *$ & 1.12 & -0.04 & $0.08 * *$ & 3.62 \\
\hline & \pm 2.00 & \pm 10.33 & \pm 1.00 & \pm 0.01 & \pm 0.02 & \pm 9.43 & \pm 0.80 & \pm 1.50 & \pm 0.03 & \pm 7.67 \\
\hline \multirow[t]{2}{*}{$\mathrm{H}_{1}$} & $15.00 * *$ & $69.78 * *$ & $5.07 * *$ & $0.12 * *$ & $0.19 * *$ & $126.07 * *$ & $7.71 * *$ & $10.35 * *$ & $0.29 * *$ & $67.40 * *$ \\
\hline & \pm 2.00 & \pm 10.37 & \pm 1.00 & \pm 0.01 & \pm 0.02 & \pm 9.46 & \pm 0.80 & \pm 1.51 & \pm 0.03 & \pm 7.70 \\
\hline \multirow[t]{2}{*}{$\mathrm{H}_{2}$} & $12.61 * *$ & $60.91 * *$ & $4.70 * *$ & $0.11 * *$ & $0.14 * *$ & $89.26^{* *}$ & $5.59 * *$ & $9.37 * *$ & $0.20 * *$ & $59.23 * *$ \\
\hline & \pm 1.76 & \pm 9.14 & \pm 0.88 & \pm 0.01 & \pm 0.02 & \pm 8.33 & \pm 0.71 & \pm 1.33 & \pm 0.03 & \pm 6.80 \\
\hline \multirow[t]{2}{*}{ h2 } & $10.85 * *$ & $127.25^{* *}$ & $1.10 * *$ & 0.01 & $0.05 * *$ & $21.47^{* *}$ & $0.42 * *$ & $9.02 * *$ & $0.16 * *$ & $142.19 * *$ \\
\hline & \pm 1.18 & \pm 6.14 & \pm 0.19 & \pm 0.01 & \pm 0.01 & \pm 5.60 & \pm 0.07 & \pm 0.89 & \pm 0.02 & \pm 4.56 \\
\hline \multirow[t]{2}{*}{$\mathrm{E}$} & $2.15^{* *}$ & $3.50 * *$ & $0.37 * *$ & $0.02 * *$ & $0.03 * *$ & 0.10 & 0.01 & $0.79 * *$ & $0.02 * *$ & $6.60 * *$ \\
\hline & \pm 0.29 & \pm 1.52 & \pm 0.14 & \pm 0.01 & \pm 0.01 & \pm 1.38 & \pm 0.11 & \pm 0.22 & \pm 0.01 & \pm 1.13 \\
\hline$\left(\mathrm{H}_{1} / \mathrm{D}\right) 0.5$ & 1.92 & 0.88 & 0.85 & 2.09 & 1.00 & 2.38 & 4.19 & 25.78 & 2.60 & 2.80 \\
\hline $\mathrm{H}_{2} / 4 \mathrm{H}_{1}$ & 0.21 & 0.21 & 0.23 & 0.22 & 0.17 & 0.17 & 0.18 & 0.22 & 0.17 & 0.21 \\
\hline $\begin{array}{l}\left(4 \mathrm{DH}_{1}\right) 1 / 2+\mathrm{F} / \\
\left(4 \mathrm{DH}_{1}\right) 1 / 2-\mathrm{F}\end{array}$ & 1.45 & 0.84 & 1.33 & 1.14 & 2.73 & 2.28 & 1.88 & 0.90 & 2.11 & 1.16 \\
\hline $\mathrm{h} 2 / \mathrm{H}_{2}$ & 0.86 & 2.09 & 0.23 & 0.09 & 0.36 & 0.24 & 0.08 & 0.96 & 0.80 & 2.40 \\
\hline h2 (ns) & 0.25 & 0.75 & 0.64 & 0.33 & 0.39 & 0.28 & 0.34 & 0.14 & 0.30 & 0.23 \\
\hline h2 (bs) & 0.70 & 0.95 & 0.91 & 0.91 & 0.88 & 1.00 & 1.00 & 0.78 & 0.87 & 0.76 \\
\hline
\end{tabular}

* Significant at 5\% level of probability; ** Significant at $1 \%$ level of probability 


\section{B. The interpretation of $\mathrm{Wr} / \mathrm{Vr}$ graph and $\mathrm{Wr}+\mathrm{Vr} /$ parental mean graph}

In $\mathrm{Wr} / \mathrm{Vr}$ graphs, the two directional depictions made based on the parental variance $(\mathrm{Vr})$ and parent offspring covariance $(\mathrm{Wr})$ and graphical tests with $\mathrm{Wr}+\mathrm{Vr}$ versus parental means are presented in the Figures 1 through 10 for the 10 characters studied. The analysis of variance due to parents and diallel progenies indicated significant differences warrant for further analysis. In this approach Hayman's graphical analysis was done and the findings are presented individually for the ten characters below.

\section{Days to 1st harvest}

The regression line of the $\mathrm{Wr} / \mathrm{Vr}$ graph (Fig. 1A) had a slope significantly different from $1.0(0.48 \pm 0.11)$ indicated non-allelic interaction for this character and intersected the $\mathrm{Wr}$ axis below the origin which indicated over dominance. Furthermore, all the $\mathrm{Wr}, \mathrm{Vr}$ points were captured within the boundary of the limiting parabola. The relative positions of the $\mathrm{Wr}, \mathrm{Vr}$ points on the $\mathrm{Wr} / \mathrm{Vr}$ graph suggest the dominance over of the parents. The parents P5 and P4 moved nearest from origin whilst P1, P6 and P2 moved to the intermediate whereas P7 and P3 were farthest from the origin. Similar findings were reported by $[11,14]$ in bean. The graph $\mathrm{Wr}+\mathrm{Vr}$ against the parental mean further confirms the diversity among the parents (Fig. 1B). Here P7 fell farthest from the intersecting point of the regression line with the parental axis and were also the latest to flower whilst in contrast parent $\mathrm{P} 4$ were closest to the origin of parental axis having mostly recessive alleles and were also the earliest to flower as evidenced from the parental means. Similar findings were reported by [16] in eggplant.

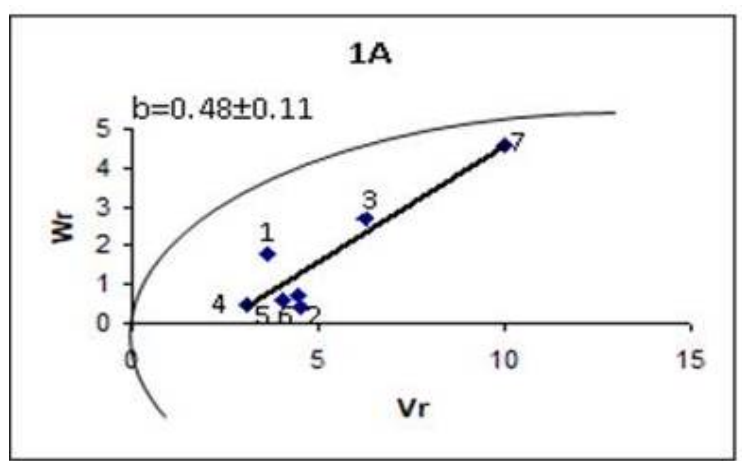

Fig. 1A. Wr, Vr regression and limiting parabola for days to $1^{\text {st }}$ harvest.

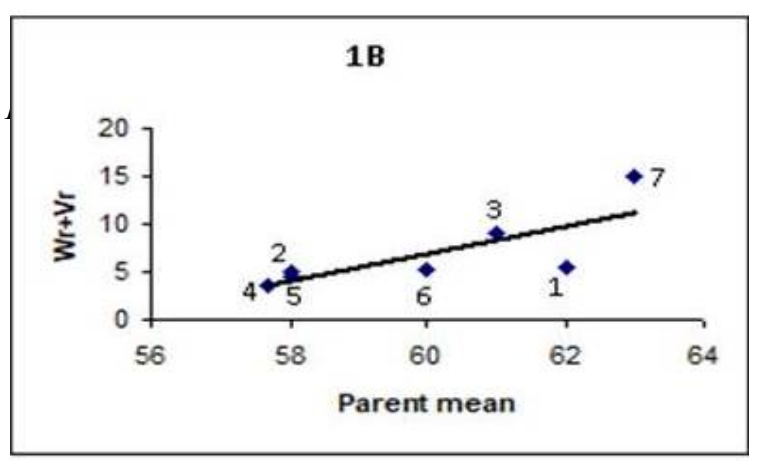

Fig. 1B. Wr+Vr Vs parental mean for days to $1^{\text {st }}$ harvest.

\section{Fruit length}

The regression line of $\mathrm{Wr} / \mathrm{Vr}$ graph (Fig. 2A) for the trait had a slope significantly different from $1.0(0.68 \pm 0.15)$ indicated non-allelic interaction and intersected the $\mathrm{Wr}$ axis above the origin indicating partial dominance. The array position changed a little, while parent P6 and P5 from closer and farthest end moved to middle position and P7 and P3 from middle group moved to the close and farthest end. The fluctuation might be due to change of growing season. Parents cluster formed into 2 indistinct groups on the regression line showing diversity in the parents for this trait. Similar findings were obtained by [19] in pumpkin, $[11,14]$ in bean and [16] in eggplant. The $\mathrm{Wr}+\mathrm{Vr} /$ parental mean graph further test the consistency of dominance against the parental score (Fig. 2B). Parental mean for the trait suggested that the parents having most dominant alleles were high scoring and parents having most recessive alleles were low scoring in general. Therefore, higher fruit length was associated with parents having dominant alleles.

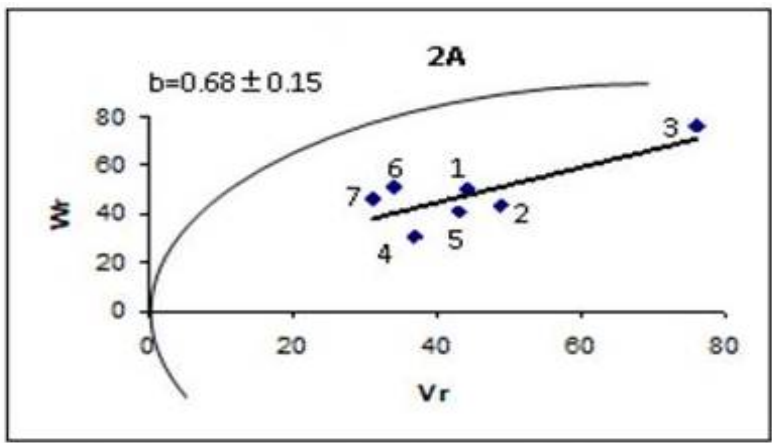

Fig. 2A. Wr, Vr regression and limiting parabola for fruit length.

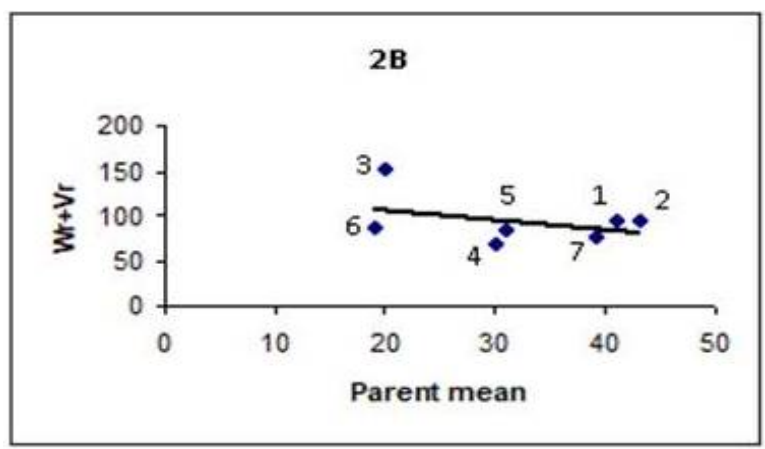

Fig. 2B. Wr+Vr Vs parental mean for fruit length.

\section{Fruit diameter}

For fruit diameter, the regression line of the $\mathrm{Wr} / \mathrm{Vr}$ graph (Fig. 3A) had a slope not significantly different from 1.0 $(0.81 \pm 0.04)$ indicated absence of non-allelic interaction and intersected the $\mathrm{Wr}$ axis almost through to the point of origin indicated the existence of nearly complete dominance. All the $\mathrm{Wr}, \mathrm{Vr}$ points lay within the boundary of the limiting parabola. It was evident from array position in $\mathrm{Wr} / \mathrm{Vr}$ graph that the parent P4, P5 and P7 had mostly dominant alleles and P6 had mostly recessive alleles. The parents P4, P7 and P2 were dominant and P3 and P6 were recessive while others were intermediate. Similar findings were obtained by [19] in pumpkin, [14] in bean and [16] in eggplant. The $\mathrm{Wr}+\mathrm{Vr} /$ parental mean graph further confirms the consistency of dominance against parental 
score and the parental means for the trait suggested that the parents having most dominant alleles were higher fruit diameter scoring and parents having most recessive alleles were lower fruit diameter scoring (Fig. 3B). So, higher fruit diameter was associated with parents having dominant alleles in the direction of higher values.

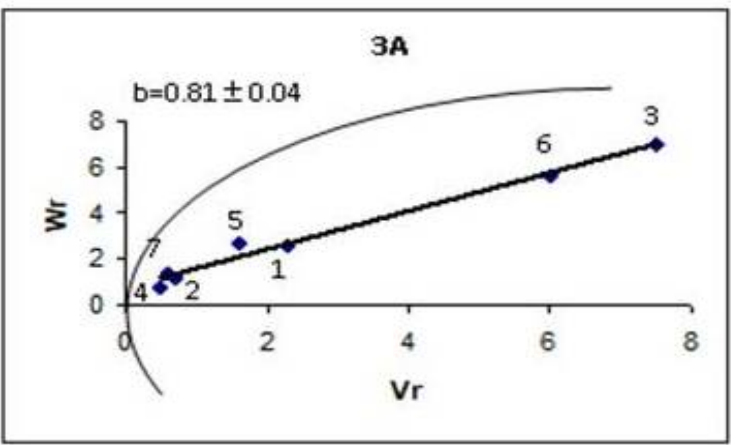

Fig. 3A. Wr, Vr regression and limiting parabola for fruit diameter.

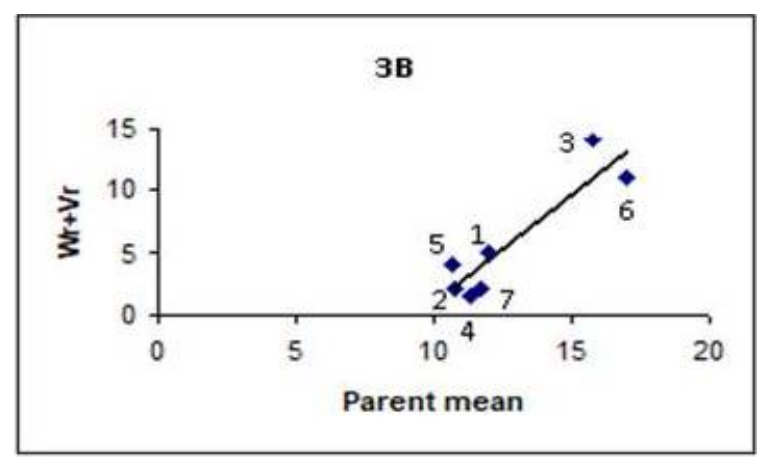

Fig. 3B. Wr+Vr Vs parental mean for fruit diameter.

\section{Exocarp thickness}

It was observed from the $\mathrm{Wr} / \mathrm{Vr}$ graph (Fig. 4A) that the regression line had a slope of $0.41 \pm 0.14$ which was significantly different from 1.0 indicating presence of nonallelic interaction. The regression line was below the point of origin indicated over dominance. The array position changed with $\mathrm{P} 2$ closer to origin whereas $\mathrm{P} 3$ remains in the farthest position, while the other 5 parents fell in between these and occupied intermediate positions. Similar result was obtained by [19] in pumpkin. The $\mathrm{Wr}+\mathrm{Vr} /$ parental mean graph confirms that the parents which contained the most recessive alleles were low scoring in general whereas parent P3 with most dominant alleles were high scoring (Fig. 4B). Therefore, parents having higher exocarp thickness was consistent by associated with dominant alleles in the direction of higher values.

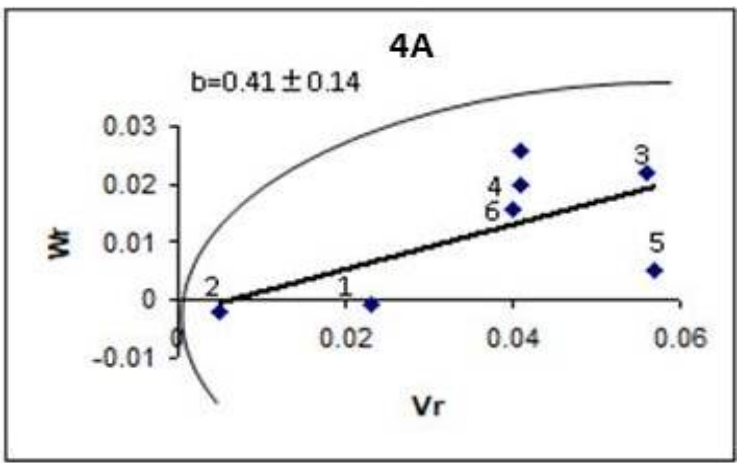

Fig. 4A. Wr, Vr regression and limiting parabola for exocarp thickness.

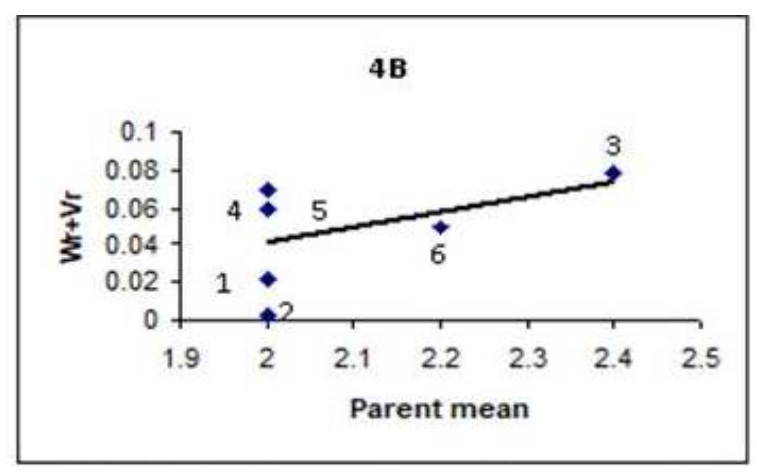

Fig. 4B. Wr+Vr Vs parental mean for exocarp thickness.

\section{TSS}

The regression line of $\mathrm{Wr} / \mathrm{Vr}$ graph for TSS (Fig. 5A) had a slope not significantly different from $1.0(1.18 \pm 0.29)$ indicated gene interaction was present and intersected the $\mathrm{Wr}$ axis well below the origin suggesting over dominance. The array position become changed with parent P2 as closest to origin and P6 and P5 the farthest position, others in the intermediate cluster. The fluctuation might be due to change of growing season. Similar result was obtained by [19] in pumpkin. The $\mathrm{Wr}+\mathrm{Vr} /$ parental mean graph showed that the parents which contained the most recessive alleles were low scoring in general whereas parent P1, P6 with most dominant alleles were high scoring (Fig. 5B).

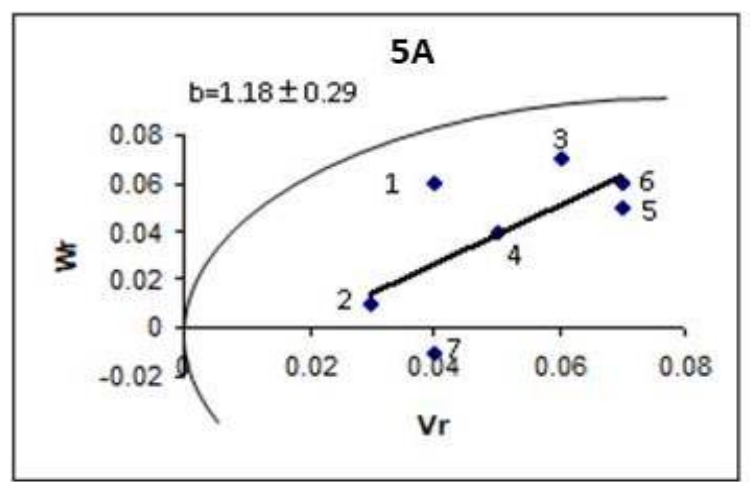

Fig. 5A. Wr, Vr regression and limiting parabola for TSS.

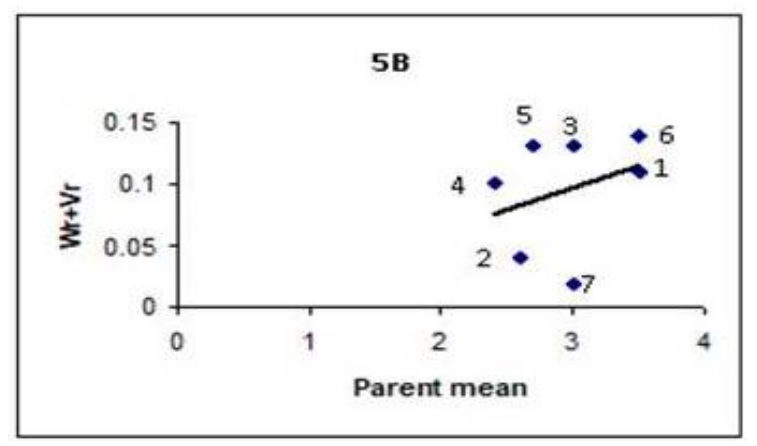

Fig. 5B. Wr+Vr Vs parental mean for TSS.

\section{Branches per plant}

The regression line of $\mathrm{Wr} / \mathrm{Vr}$ graph (Fig. 6A) for branches per plant had a slope significantly different from $1.0(0.35 \pm$ $0.15)$ indicated non-allelic interaction and intersected the $\mathrm{Wr}$ axis above and below the point of origin suggesting partial dominance and over dominance. The parent P1 and P2 were the closest to origin being most dominant alleles and P5 was the farthest from origin being most recessive alleles. Similar findings were reported by [16] in eggplant. 
The $\mathrm{Wr}+\mathrm{Vr}$ versus parental mean graph confirmed that the branch per plant was conditioned by dominant alleles with high scoring parents P3 (Fig. 6B).

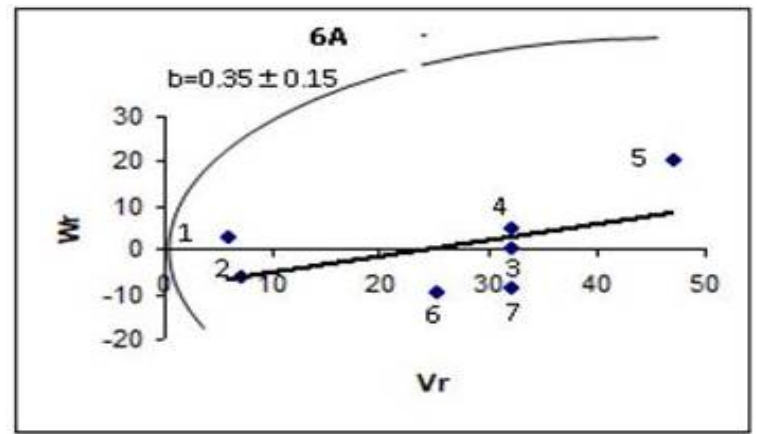

Fig. 6A. Wr, $\mathrm{Vr}$ regression and limiting parabola for branches per plant.

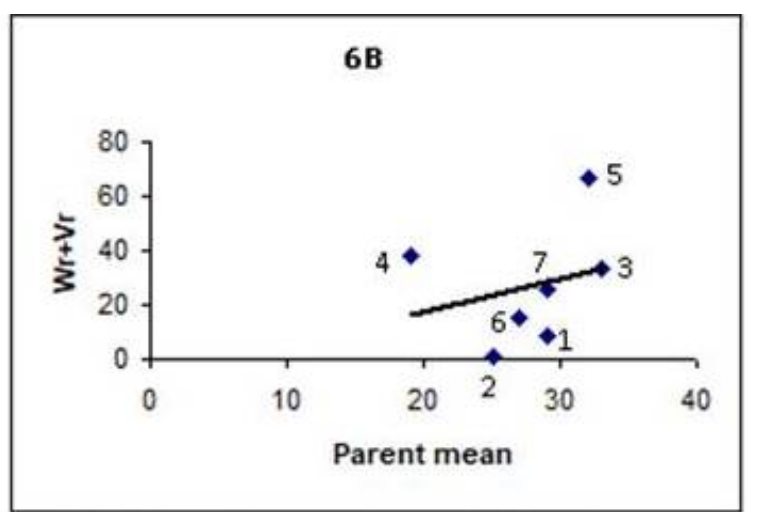

Fig. 6B. Wr+Vr Vs parental mean for branches per plant.

\section{Vine length}

It was observed from the $\mathrm{Wr} / \mathrm{Vr}$ graph (Fig. 7A) that the slope of the regression line had significantly different value than unity $(0.07 \pm 0.07)$ indicating presence of non-allelic interaction. The regression line intersected the $\mathrm{Wr}$ axis below the point of origin suggesting over dominance in addition to the interaction. The relative position of arrays showed that the parent P1 fell nearest to the origin having most dominant alleles and parent P5 fell farthest from the point of origin with most recessive alleles. The remaining 5 other parents fell in intermediate position with equal frequency of dominant and recessive alleles. Similar findings were obtained by [11] in bean. The $\mathrm{Wr}+\mathrm{Vr}$ versus parental mean graph confirms that the vine length was conditioned by dominant alleles with high scoring parents in general with a little inconsistency about the control of dominance in high scoring parents (Fig. 7B).

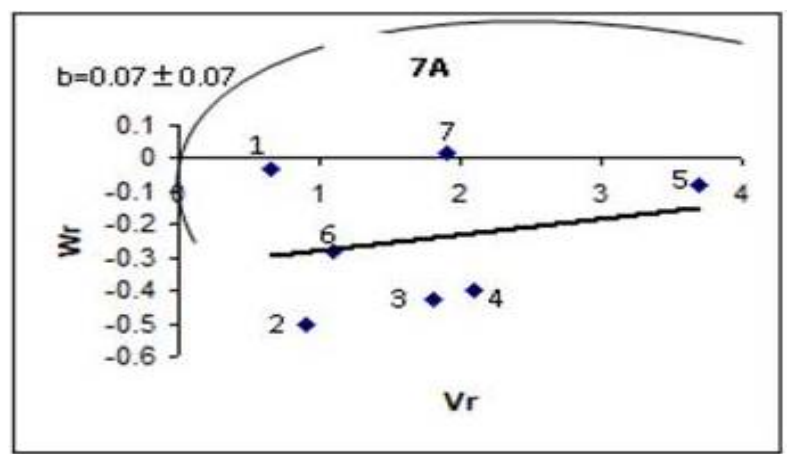

Fig. 7A. Wr, Vr regression and limiting parabola for vine length.

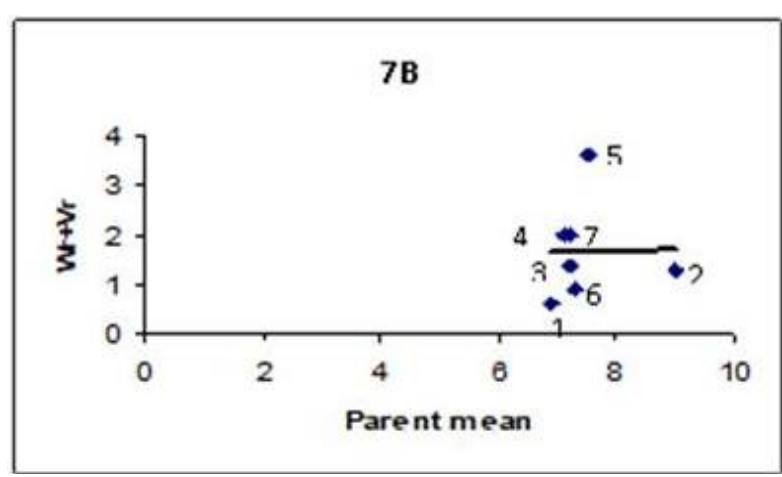

Fig. 7B. and Wr+Vr Vs parental mean for vine length.

\section{Fruits number per plant}

For fruits number per plant, the regression line of the $\mathrm{Wr} / \mathrm{Vr}$ graph (Fig. 8A) had a slope significantly different from 1.0 $(0.10 \pm 0.07)$ indicated non-allelic interaction and intersected the $\mathrm{Wr}$ axis almost below to the point of origin indicated the existence of nearly over dominance. All the $\mathrm{Wr}$, Vr points lay within the boundary of the limiting parabola. From array position in $\mathrm{Wr} / \mathrm{Vr}$ graph that the parent P3 had mostly dominant alleles and P1 had mostly recessive alleles. The other parents have middle groups with equal frequency of dominant and recessive alleles. Similar findings were reported by $[11,14]$ in bean and [16] in eggplant. The $\mathrm{Wr}+\mathrm{Vr} /$ parental mean graph further confirms the consistency of dominance against parental score and the parental means for the trait suggested that the parents having most dominant alleles were high scoring and parents having most recessive alleles were low scoring (Fig. 8B). So, more fruits number was associated with parents having dominant alleles in the direction of higher values.

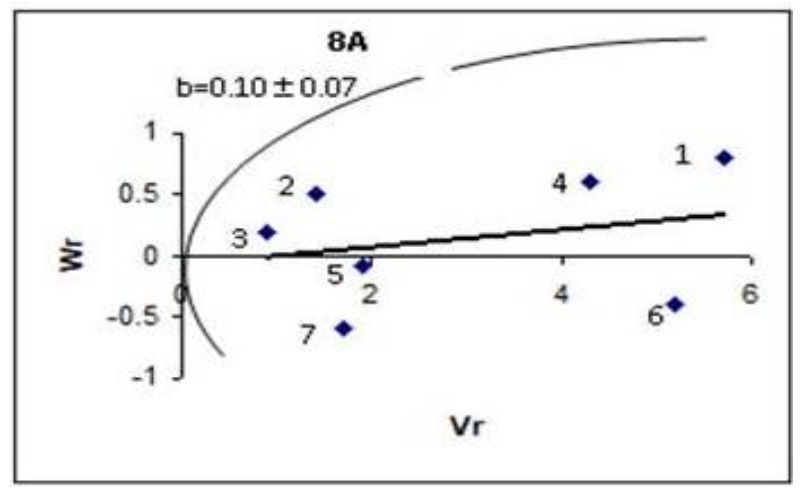

Fig. 8A. Wr, Vr regression and limiting parabola for fruits per plant.

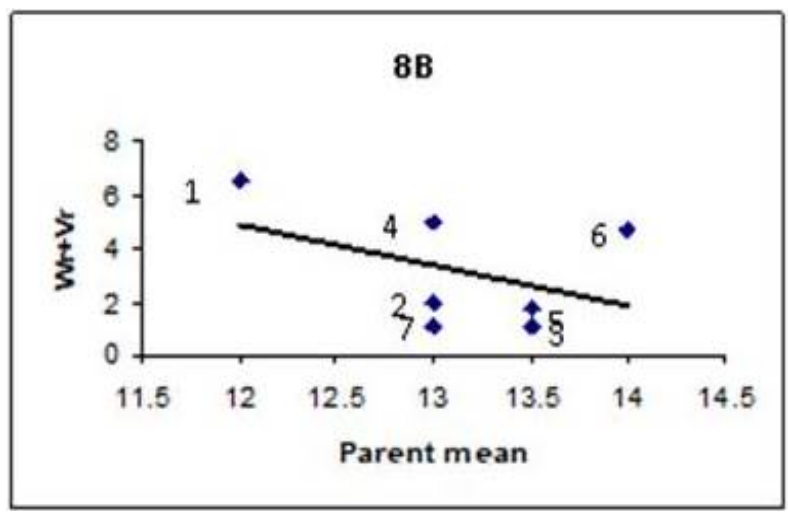

Fig. 8B. Wr+Vr Vs parental mean for fruits per plant. 


\section{Average fruit weight}

It was observed from the $\mathrm{Wr} / \mathrm{Vr}$ graph (Fig. 9A) that the regression line had a slope of $0.12 \pm 0.12$ which was significantly different from 1.0 indicating presence of nonallelic interaction. The regression line intersected the $\mathrm{Wr}$ axis below the point of origin indicated over dominance. The relative values of the $\mathrm{Wr}$ and $\mathrm{Vr}$, parent $\mathrm{P} 2$ closer to origin and P6 moved to the farthest position and other remains in the intermediate group. Similar findings were reported by [14] in bean and [16] in eggplant. The $\mathrm{Wr}+\mathrm{Vr} /$ parental mean graph confirms that the parents which contained the most dominant alleles were high scoring in general whereas parents with most recessive alleles were low scoring (Fig. 9B). Therefore, parents having high average fruit weight was consistent by associated with dominant alleles in the direction of higher values.

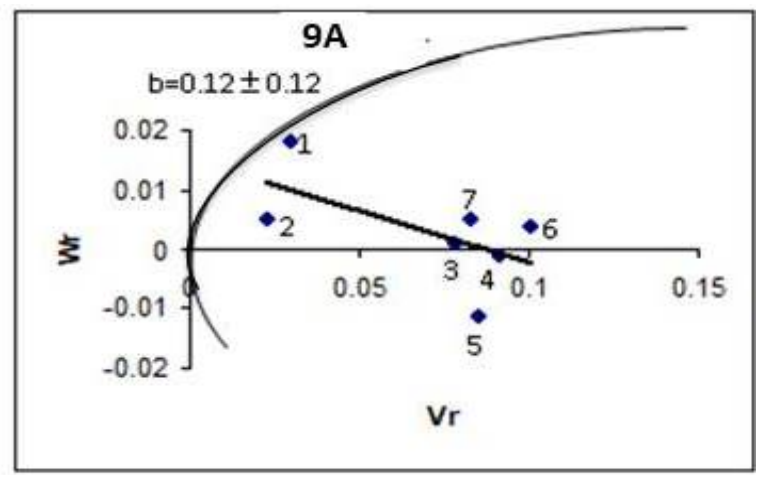

Fig. 9A. Wr, Vr regression and limiting parabola for fruit weight.

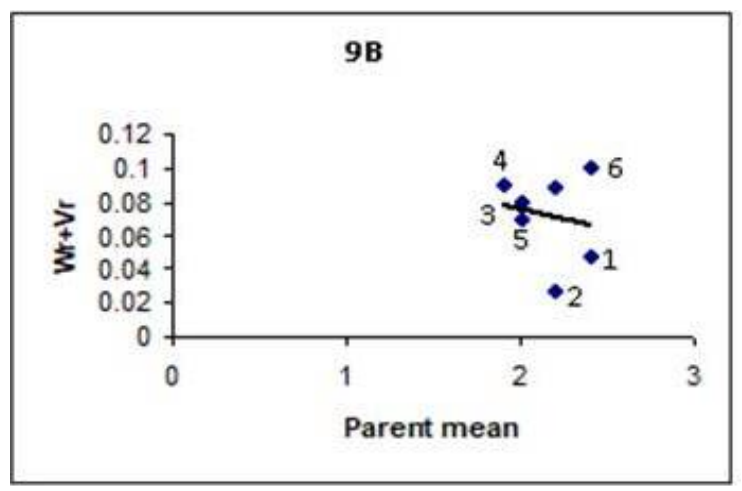

Fig. 9B. Wr+Vr Vs parental mean for fruit weight.

\section{Yield per plant}

The slope of the regression line for yield per plant (Fig. $10 \mathrm{~A})$ was significantly below $1.0(0.36 \pm 0.11)$, suggesting significant non-allelic interaction for this character. Similar findings were reported by [18] in bottle gourd. The regression line intersected the $\mathrm{Wr}$ axis slightly below the origin suggested over dominance, in addition to the interaction. The relative values of $\mathrm{Vr}$ and $\mathrm{Wr}$ showed that the parent P6 had the lowest value being the most dominant alleles while the parent $\mathrm{P} 4$ had the highest $\mathrm{Vr}, \mathrm{Wr}$ values and have the most recessive alleles. The fluctuation might be due to change of growing season. Similar findings were reported by [19] in pumpkin, $[11,14]$ in bean and [16] in eggplant. The $\mathrm{Wr}+\mathrm{Vr} /$ parental mean confirms the parents which contained the most dominant alleles were high scoring in general while parents with most recessive alleles were low scoring (Fig. 10B). Parents having high yield was consistently associated with dominant alleles in direction of higher values.

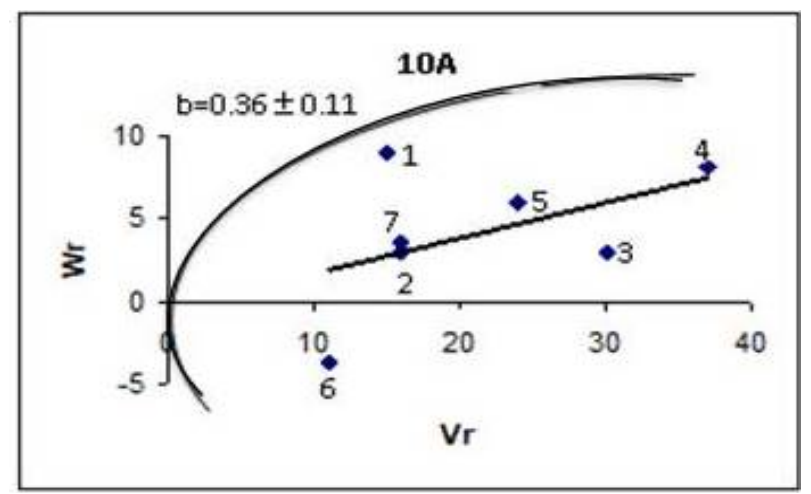

Fig. 10A. Wr, Vr regression and limiting parabola for fruit yield per plant.

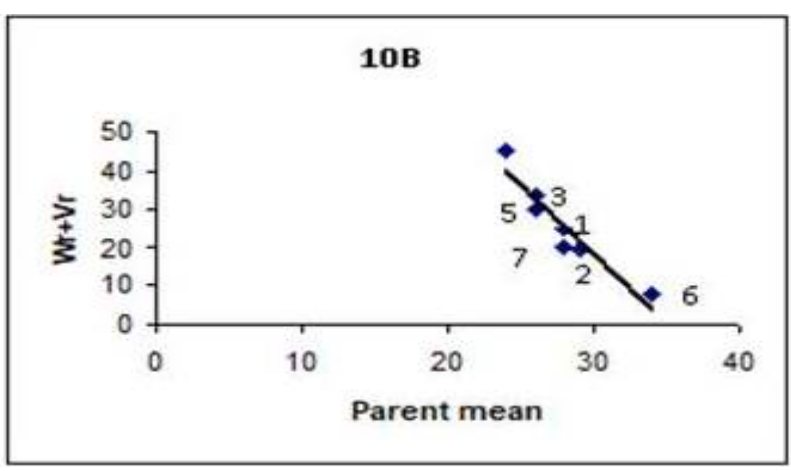

Fig. 10B. Wr+Vr Vs parental mean for fruit yield per plant.

\section{CONCLUSION AND RECOMMENDATION}

The graphical and the component of variance analysis revealed that non-additive gene action were dominant in all the characters studied. But the average degree of dominance was over dominance in the inheritance of maximum traits in except fruit length, fruit diameter, endocarp thickness showed the partial dominance for the genes controlling these characters. The values of the ratio of number of total dominant and recessive gene estimated were one or more than one for most of the characters except fruit length and fruits number per plant indicating the asymmetrical distribution of dominant and recessive alleles in the parents for the eight characters and an excess of dominant gene is indicated. Broad sense heritability was higher heritability for all the parameters but in narrow sense heritability were higher heritability for fruit length, fruit diameter, endocarp thickness indicating their high heritable control nature. The $\mathrm{Wr} / \mathrm{Vr}$ graphs showed dominance effect of gene was observed in maximum characters. Therefore it may be concluded that the heterosis breeding may be advantageous to get higher production in bottle gourd.

\section{ACKNOWLEDGEMENT}

The authors would like to thank the Olericulture Division, Horticulture Research Center, Bangladesh Agricultural Research Institute, Gazipur, Bangladesh for the support and allowing this research study. 


\section{REFERENCES}

[1] Anonymous. 1995. Agro-climatatrological data. Agromet Division, Bangladesh Meteorological Department, Joydebpur, Gazipur. pp. 3565.

[2] Askel R and L.P.V. Johnson. 1963. Analysis of a diallel cross: A worked example. Advancing Frontiers Pl. Sci. 2:37-54.

[3] Biswas, P.S. and M. Enamul Haque. 2007. Gene action of agronomic traits in rice (Oryza sativa L.). Bangladesh J. Pl. Breed. Genet. 20(2): 31-36.

[4] Dey, S. S., T.K. Behera, A.D. Munshi, S. Rakshit and R. Bhatia. 2012. Utility of gynoecious sex form in heterosis breeding of bitter gourd and genetics of associated vegetative and flowering traits. Indian J. Hort. 69(4): 523-529.

[5] Gardner, C.O. 1963. Estimation of genetic parameters in cross fertilizing plants and their implications. In: Plant Breeding by W.D. Hanson and F.F. Robinson (eds.), NAS-NRC Pub. Washington. pp. 225-252.

[6] Gautam D.K. and G.C Yadav. 2017. Gene action for growth, yield and quality traits in bottle gourd [Lagenaria siceraria (Mol.) Standl]. Journal of Pharmacognosy and Phytochemistry. 6(4): 84-88.

[7] Haq, M.I. 2009. Genetic analysis of grain yield and its components in maize. Sarhad J. Agric. 25(2): 187-195.

[8] Hayman, B.I. 1954a. The analysis of variance of diallel table. Biometrics. 10: 235-244.

[9] Hayman, B.I. 1954b. The theory and analysis of diallel crosses. Genetics. 39: 789-809.

[10] Hayward MD. 1979. The application of the diallel cross to outbreeding crop species. Euphytica. 28:729-737.

[11] Islam, A.K.M.A., M.M.A. Jahan and M.A. Newaz. 2006. Diallel analysis for gene action in dry bean (Phaseolus vulgaris L.). Bangladesh J. Pl. Breed. Genet. 19(2): 7-14.

[12] Jinks J.L, B.I. Hayman. 1953. The analysis of diallel crosses. Maize Genetics Newsletter. 27:48-54.

[13] Jinks, J.L 1954. The analysis of continuous variation in a dial lei cross of Nicotiana rwtica varieties. Genetics. 39: 767-788.

[14] Kabir, M.Y., N. Sultana, M.M. Rahman and M.A.K. Mian. 2006. Genetic analysis for agronomic characters in lablab bean (Lablab purpureus (L.) Sweet). Bangladesh J. Pl. Breed. Genet. 19(2): 31-36.

[15] Pandey, S. K., S.B.L. Srivastava, N.P. Singh and J.P. Srivastava. 2004. Heterosis and combining ability for earliness in bottle gourd (Lagenaria siceraria (Molina) Standl.). Veg. Sci. 31: 11-16.

[16] Quamruzzaman, A.K.M., S. Ahmad and M. Moniruzzaman. 2008. Gene action for yield components in eggplant (Solanum melongena L.). Ann Bangladesh Agric. 12(2): 93-96.

[17] Quamruzzaman, AKM, S. Ahmad .2010. Genetic analysis of some yield components of bottle gourd [Lagenaria siceraria (Mol.) Standl.]. J Agric 8:1-9.

[18] Quamruzzaman, AKM, M.M.R.Salim, L. Akhter, T. Hasan, Khairul Mazed, M.A.Z. Chowdhury. 2019. Genetic Architecture of Yield in Bottle Gourd (Lagenaria siceraria (Mol.) Standl.). Agricultural Sciences, 10:567-576. DOI: 10.4236/as.2019.104045.

[19] Rana, M.S., M.G.Rasul, A.K.M.A. Islam and M.M.Hossain. 2016. Diallel Analysis of Quality and Yield Contributing Traits of Pumpkin (Cucurbita moschata Duch. ex Poir.). The Agriculturists 14(1): 1532.

[20] Reyes, M.E.C, E.C. Altoveros, E.T. Rasco Jr, E.B. Guevarra. 1993. Combining ability and heterosis for yield and yield components in bottle gourd (Lagenaria siceraria (Mol.) Standl.). Scientific Meeting of the Federation of Crop Science Societies of the Philippines. Aklan (Philippines).

[21] Sharma, J.R. 1998. Statistical and biometrical techniques in plant breeding. New Age International (P) Ltd. India. p.432.

[22] Sharma N, N.K. Sharma, Y.K. Malik. 2010. Estimation of genetic variation in bottle gourd, In: Abstract book of National Seminar on Recent Trends in Hort. Crops Issues and Strategies for Res. Development, March 22-24, CCS HAU, Hissar. 26.

[23] Singh, S.K, R.K. Singh, S.S. Solankey, A.K. Upadhyay. 2012. Studied on genetic causes of heterosis in bottle gourd (Lagenaria siceraria (Mol.) Standl.) near hangetic region of Varanasi. Asian J Hort 7: 303-306.

[24] Sirohi, PS, N. Sivakami, B. Choudhary. 1986. Genetic analysis in long fruited bottle gourd. Indian J. Agric. Sci. 56:623-625

[25] Sit, A.K, P.S. Sirohi.2008. Genetic architecture of yield and yield attributing characters of bottle gourd. Ind J Hort 65: 243-244.

[26] Sit, A.K, P.S. Sirohi. 2000. Gene action of nutritional traits in bottle gourd (Lagenaria siceraria (Mol.) Standl.). Veg. Sci. 27:25-27.

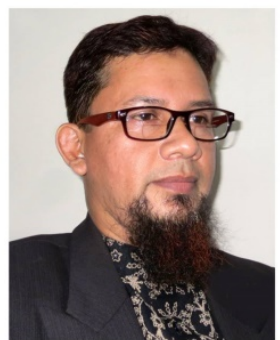

AKM Quamruzzaman born in Dhaka, Bangladesh and got $\mathrm{PhD}$ degree in Horticulture major with Vegetables Breeding From Bangabandhu Sheikh Mujibur Rahman Agricultural University (BSMRAU) in 2011. At present he is currently employed as PRINCIPAL SCIENTIFIC OFFICER at Olericulture Division, BARI, Gazipur, Bangladesh. As a vegetable scientist, he is the principal breeder of Solanaceous and Cucurbitaceous vegetables research. $\mathrm{He}$ developed more than 25 vegetables varieties and published more than 60 scientific articles. Dr. Quamruzzaman is an active member of American Society for Horticultural Science (ASHS), Bangladesh Society for Horticultural Science (BSHS), Plant Breeding and Genetics Society of Bangladesh (PBGSB) and also serving as project investigator of FAO, AFACI, WordVeg, NATP, SACP-IFAD.

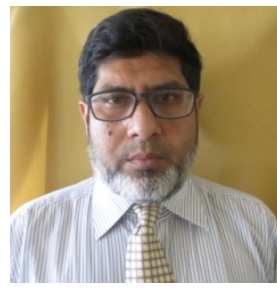

Md. Mahbubar Rahman Salim born in Rangpur, Bangladesh and got $\mathrm{PhD}$ degree in Horticulture major with Vegetables Breeding From BSMRAU in 2013. At present he is currently employed as SENIOR SCIENTIFIC OFFICER at Olericulture Division, BARI, Gazipur, Bangladesh. He is responsible for Malvaceae and Cucurbitaceous vegetables research, developed 5 vegetables varieties and published more than 20 scientific articles. Dr. Salim is an active member of BSHS, PBGSB, BAS and KIB and also serving as project investigator of different national and international development projects.

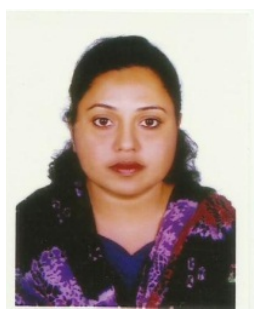

Limu Akter born in Gopalganj, Bangladesh and got MS (in Agricultural Extension Education, BAU) and (in Horticulture, Vegetables Breeding, BSMRAU). Now a PhD fellow in Horticulture with vegetable breeding in BAU. At present she is currently employed as SCIENTIFIC OFFICER at Olericulture Division, BARI, Gazipur, Bangladesh. As a vegetable scientist, she is the breeder of Solanaceous and cucurbitaceous vegetables research. She involved more than 11 vegetables varieties and published more than 13 scientific articles. Limu Akter is an active member of BSHS, PBGSB, Bangladesh Entomological Society.

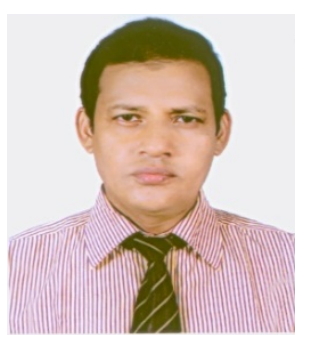

Md. Mustafizur Rahman born in Thakurgaon, Bangladesh and obtained B.Sc.Ag.(Hons) degree from Bangladesh Agricultural University, Mymensingh in 1990 and MS (Environmental Science and Management), MBA (Finance and Banking) and PGD (Journalism). Mr. Rahman is currently employed as PRINCIPAL TECHNICAL OFFICER at Bangladesh Agricultural Research Council (BARC), Dhaka, Bangladesh and published 20 scientific/ articles. Mr. Rahman served as the Principal Investigator of the IFPRI, FAO funded project. Mr. Rahman is a member of KIB.

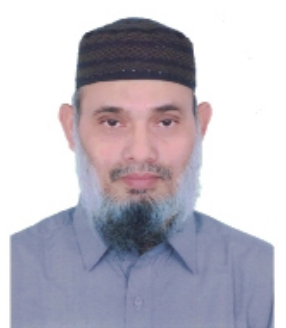

Md. Aziz Zilani Chowdhury born in Moulvibazar, Bangladesh and got PhD degree in Genetics and Plant Breeding major with Oilseed Breeding from BSMRAU, Bangladesh in 2002. He did his Post Doctoral program in Biosafety Measures in Crop Biotechnology from University of Lincoln, UK in 2013. As a breeder he developed more than 12 varieties of rapeseed-mustard, peanut, sunflower, sesame etc. and published 50 scientific articles. At present he is currently employed as Member Director of Crops Division, BARC, Dhaka-1215, Bangladesh. He also involved in crop improvement and crop management research program planning and monitoring of National Agricultural Research System (NARS). Dr. Chowdhury is an active member of PBGSB, Asiatic Society of Bangladesh. At present he is elected as President of PBGSB. He also implemented project as project investigator/coordinator of different national and international development projects. 